\title{
Analysis of Modernized Value Chain of Walnut in Jammu \& Kashmir
}

\author{
N.A. Qammer ${ }^{1}$ and S.H. Baba*2
}

${ }^{1}$ Sher-e- Kashmir University of Agricultural Sciences and Technology, Shalimar campus, Srinagar, 190025 (J\&K), India ${ }^{2}$ Division of Agricultural Economics \& Marketing SKUAST-Kashmir, Shalimar Campus, Srinagar 190025 (J\&K), India

*Corresponding author: meharnn@gmail.com

\begin{abstract}
This study intends to investigate the modernized supply chain of walnut in Jammu \& Kashmir. The study reported that modernized supply chain involves huge investment and that the value addition of walnut in their processing units are exclusively earmarked for export markets. It was observed that setting up of a processing unit for value addition of walnut is a capital intensive activity. Moreover, in modernized channels, processors were found to pay better to the functionaries from whom they purchase walnut. Results revealed that the marketing efficiency was more in channel where they purchase directly from farmers and also their net price is more in this channel. Based upon the findings, the study emphasized upon linking walnut production with marketing through value addition. In addition, this paper concluded with few pragmatic policy options for the promotion of exports, reduction of losses and sustainable growth of this fruit in Jammu \& Kashmir.
\end{abstract}

Keywords: Walnut, value chain, marketing margin, marketing efficiency

The post-harvest losses in this fruit are significant in terms of quantity and resultant economic value. The concept of placing emphasis on increased production of fruits is self-defeating. It is important to see how the produce goes through processing and finally reaches the export market. Efforts should be made to integrate production with post-harvest management to improve its availability by reducing its losses. Walnut is more widely grown after apple in Jammu and Kashmir. Major proportion of exportable surplus of walnut is contributed by Jammu and Kashmir State and has been a major source of cash income for walnut growers. Walnut holds a good place in trade owing to its high demand in national and international market. However, the poor marketing system has deprived growers from the benefits that actually should accrue to them. Processing of this fruits at farm level could be an option for such problems but inadequate and unscientific processing resulted in qualitative loss, which is more serious and can infected the produce unsuitable for human consumption (Eckert, 1978; Naqvi and Dass, 1994; Singh and Jain, 2004).

Although number of references relating to estimation of post-harvest losses and value addition in several fruits are available in literature (Gajanana et al. 2002; Sreenivasa Murthy et al. 2002; and Kishore Kumar et al. 2006), a very little work has been done regarding walnut in India. Realizing the economic importance of walnut, this paper investigated into the analysis of losses, and modernized value chain of walnut in Jammu and Kashmir.

\section{MATERIALS AND METHODS}

Primary data was analyzed for this investigation and was collected from 4 processors, 110 sample respondents of 9 selected in a village cluster from Dachnipore block of district Anantnag, and also from appropriate number of other functionaries for obtaining relevant information relating to various aspects of walnut export and estimation of losses during export. The data were collected from walnut 
growers and processors by personal contact method on a well designed and pre-tested schedule during 2014-15.

Marketing efficiency was computed by using the following corrected marketing efficiency measure, given by Acharya and Agarwal (2001), as this measure explicitly incorporates "Marketing loss" in the existing marketing efficiency ratio. Further all costs and margins were estimated with respect to price received by processors.

Marketing efficiency $=$

Net price received by farmer $\left(\mathrm{NP}_{\mathrm{F}}\right)$

Total marketing cost $(\mathrm{MC})+$ Total marketing margin $(\mathrm{MM})+$ Marketing loss (ML)

\section{RESULTS AND DISCUSSION}

\section{Utilization Pattern and Marketable Surplus of walnut}

The utilization pattern of walnut by the sample farmers, presented in Table 1 , revealed that the marketable surplus in walnut was 92.39 per cent of the total walnut production per farm. The losses form 7.52 per cent of the total walnut produce. Only 0.09 per cent of the total walnut produce was kept for the family consumption. The total utilization, as proportion of total production in the form of losses was higher in walnut. Measures were taken to prevent the disease and insect/pest incidence, and the need to be taken to prevent various losses.

Table 1: Utilization pattern of walnut by sample households ( $q /$ farm)

\begin{tabular}{lccc}
\hline & Particulars & Qty. & \%age \\
\hline A. & Total production & 18.010 & 100.00 \\
B. & Losses & 1.354 & 7.52 \\
C. & Consumption & 0.017 & 0.09 \\
D. & Total utilization (B+C) & 1.371 & 7.61 \\
F. & Marketable surplus (A-D) & 16.64 & 92.39 \\
\hline
\end{tabular}

Two modernized marketing channels were perused by the farmer in the study area to sell their produce and the channels are given below:

$\begin{array}{llccc}\text { Channel I } & \text { Farmer } & \text { Trader } & \text { Processor } & \text { Export } \\ \text { Channel II } & \text { Farmer } & \text { Processor } & \text { Export } & \end{array}$

The modernized supply chain of walnut processor has a major role in value addition and handling produce. The various aspects of modernized value chain have been discussed below:

\section{Capital Formation and Investment Pattern}

Most of the walnut growers in Kashmir valley belongs to small farm category operating on marginal land and produces little surplus for markets. The value addition of walnut for export requires huge investment on machinery and labour. A numbers of private enterprises have a venture in this sector and they invest heavily on fixed and working capital for preparing produce for external markets. In this context, Table 2 revealed that the investment on land and buildings account for higher proportion of total capital formation at the enterprise. The important items of investment are conveyor belts $(14.93 \%)$ followed by tray dryers $(3.45 \%)$, crates $(3.54 \%)$ and kernel grader (1.74\%). Moreover, this capital stock requires regular maintenance and repairs. In this way encouragement of these enterprises require financial assistance at lower interest rates through financial institutions especially on the time when they require it most. Development subsidies to these sectors need to be improved significantly.

\section{Procurement and distribution system}

Most of the raw material comes from walnut growers across various districts, although, one of the enterprise was found to have laid his own walnut orchard. The total procurement of nuts and kernels ranged from 1000 to 3000 and 2500 to 3500 quintals, respectively. While majority of walnuts were procured from growers of district Anantnag (43\%) followed by Pulwama (40\%), Kupwara (10\%) and others $(7 \%)$, maximum proportion $(60 \%)$ of walnut as kernels come from district Anantnag and rest $(30 \%)$ from the others districts. As far as the export of value added walnut is concerned, higher proportion of surplus was found to be exported through agents while only 47 per cent of produce was being directly exported to other walnut importing countries mostly in the form of kernels. 
Table 2: Capital formation at private walnut enterprises

\begin{tabular}{|c|c|c|c|}
\hline Capital formation & $\begin{array}{l}\text { Quantity } \\
\text { (No.) }\end{array}$ & $\begin{array}{l}\text { Value(₹ in } \\
\text { lakhs) }\end{array}$ & $\begin{array}{c}\% \text { of total } \\
\text { value }\end{array}$ \\
\hline \multicolumn{4}{|l|}{ Current asset } \\
\hline Crates & 2530 & 7.68 & 3.54 \\
\hline Buckets & 755 & 1.82 & 0.84 \\
\hline Washing tubs & 65 & 0.21 & 0.1 \\
\hline $\begin{array}{l}\text { Others (hammers, } \\
\text { washing baskets, etc.) }\end{array}$ & 672 & 0.26 & 0.12 \\
\hline Sub-total (a) & 4022 & 9.98 & 4.60 \\
\hline \multicolumn{4}{|l|}{ Medium term } \\
\hline Tractor/load carrier & 0.5 & 1.47 & 0.68 \\
\hline Vacuum packer & 2 & 2.67 & 1.23 \\
\hline Semi vacuum packer & 0.5 & 1.12 & 0.52 \\
\hline Walnut grader & 1 & 2.35 & 1.08 \\
\hline Kernel grader & 2 & 3.78 & 1.74 \\
\hline $\begin{array}{l}\text { Transformer } \\
\text { (stabilizer) }\end{array}$ & 1 & 1.56 & 0.72 \\
\hline Tray dryers & 6.5 & 7.68 & 3.54 \\
\hline Conveyer belts & 3 & 32.40 & 14.93 \\
\hline Blowers & 1.5 & 0.40 & 0.19 \\
\hline Strapping machine & 1.5 & 1.17 & 0.54 \\
\hline Taping machine & 1.5 & 0.40 & 0.19 \\
\hline $\begin{array}{l}\text { Other (trollies, sealers } \\
\text { and hand graders) }\end{array}$ & 4.5 & 0.38 & 0.18 \\
\hline Sub-total (b) & 25.5 & 55.40 & 25.52 \\
\hline Long term & & & \\
\hline $\begin{array}{l}\text { Land (kanals)/ } \\
\text { buildings }\end{array}$ & 4 & 150.00 & 69.1 \\
\hline Washing tanks & 4 & 1.68 & 0.77 \\
\hline Sub-total (c) & - & 151.68 & 69.88 \\
\hline $\operatorname{Total}(a+b+c)$ & 4051.5 & 217.06 & 100 \\
\hline
\end{tabular}

\section{Value chain followed by entrepreneur}

The supply chain of walnut has been shown in Fig. 1. Fruits are harvested from the trees when the splitting of the hull and the natural fall of some nuts occur. The common harvesting practice is to beat the bearing branches with long poles (lawnz). The fallen crop is usually collected by women and children. The harvested crop with hulls is heaped for the synthesis of ethylene and left until separation of the hull is made easier. The hulling process is followed by thorough washing in fast-flowing streams. In some areas, the bleaching of nuts is also practiced to some extent. The nut crop is dried under open condition and depending on favourable weather conditions, it may take 3-5 days to dry.
The entrepreneur makes the arrangement for assembling of walnut produce from growers scattered across different regions, pack the dried walnut and transport the produce to their establishment. The private enterprises procure raw material directly from farmers with the deal of partial or full advance payment. Identified walnut growers have reported higher returns per quintal from private enterprises than pre-harvest contractors or other traders from within or outside the State. It was observed that growers preferred to sell the produce to these enterprises. Prompts payments and higher price resulted in better returns to the farmer by eliminating intermediaries. After unloading, the produce undergoes for quality check. They looked for size of walnuts, kernel percentage inside walnut and shell thickness of nuts and moisture content, colour, taste and infection (if any) in kernels for fixation of price and further value addition.

The walnuts are then graded on the basis of the size using walnut grader. It is desired to obtain full size kernels, therefore, walnuts are soaked in washing tanks for 6-10 hours for removing dirt, other contamination and for easy cracking. Soaked walnuts are then cracked by skilled female workers with the help of wooden hammers and steel coils. Skilled labours are engaged for cracking nuts so as to avoid breakage of kernels. About $37-40 \mathrm{~kg}$ of kernels are obtained from $100 \mathrm{~kg}$ of nuts depending upon shell thickness and quality of nuts.

Kernels after being extracted out of nuts are dried over tray driers and 5-10\% of moisture is retained within kernels. Then kernels undergo grading by kernel graders depending upon size. The graded produce is then placed over conveyor belts and skilled labour sort them out on the basis of kernel colour into five grades as per Table 3. During summers, in lean season, kernels are preserved with nitrogen and packed in vacuum silver packs to get over unfavourable climatic conditions. After this, the produce is prepared for final packing during peak season. Summer packs are opened and finally packed into plastic packs of varying size. Packed material is then put into corrugated boxes. After this stage, entrepreneur got an organic certification issued on the basis of the mandatory checks and other codal formalities required under Article 4(4) of Regulation (EC) 1788/2001 and as per Appendix 9 under Section 7 of India's National Programme for 
Organic Production (NPOP), which is considered equivalent to the provisions of Regulation (EEC) NO. 2092/91. The containers are fumigated with methyl Bromide to prevent any access of fungus inside it. The exporter has to get another certificate certifying that the fumigation has been carried out in accordance with the NSPM-12 and the fumigation has been performed in a container and not prior to lacquering, varnishing, painting or wrapping. Then the packed walnut kernel are exported to various Indian trade partners.

\begin{tabular}{|c|c|c|c|}
\hline $\begin{array}{l}\text { By beating the } \\
\text { bearing branches } \\
\text { with long poles }\end{array}$ & $\rightarrow$ & $\downarrow$ & \\
\hline $\begin{array}{c}\text { Heaped at one } \\
\text { place for easy } \\
\text { hulling }\end{array}$ & $\rightarrow$ & $\downarrow$ & \\
\hline $\begin{array}{l}\text { Manual in closed } \\
\text { room }\end{array}$ & $\rightarrow$ & $\begin{array}{c}\text { Hulling } \\
\qquad\end{array}$ & \\
\hline In flowing stream & $\rightarrow$ & $\begin{array}{c}\text { Washing } \\
\quad \downarrow\end{array}$ & \\
\hline $\begin{array}{l}\text { Sun drying for 5-8 } \\
\text { days }\end{array}$ & $\rightarrow$ & $\begin{array}{c}\text { Drying } \\
\quad \downarrow\end{array}$ & \\
\hline $\begin{array}{l}\text { Directly from } \\
\text { farmers on partial } \\
\text { of full advance } \\
\text { payment basis }\end{array}$ & $\rightarrow$ & Procurement & $\begin{array}{l}\text { Better returns } \\
\text { to the farmers } \\
\text { by eliminating } \\
\text { intermediaries }\end{array}$ \\
\hline $\begin{array}{l}\text { Sort out the } \\
\text { spoiled nuts }\end{array}$ & $\rightarrow$ & $\begin{array}{c}\qquad \downarrow \\
\text { Quality } \\
\text { check }\end{array}$ & $\begin{array}{l}\text { Remove } \\
\text { contamination } \\
\text { for global } \\
\text { markets }\end{array}$ \\
\hline $\begin{array}{l}\text { Walnut grader } \\
\text { is used to grade } \\
\text { walnut in } 3 \\
\text { grades on the } \\
\text { basis of size }\end{array}$ & $\rightarrow$ & Grading & $\begin{array}{l}\text { Higher prices } \\
\text { for graded } \\
\text { produce }\end{array}$ \\
\hline & & $\downarrow$ & \\
\hline $\begin{array}{l}\text { Overnight in } \\
\text { washing tubs }\end{array}$ & $\rightarrow$ & $\begin{array}{c}\text { Soaking } \\
\qquad \\
\downarrow\end{array}$ & Saves labour \\
\hline $\begin{array}{l}\text { By wooden } \\
\text { hammers }\end{array}$ & $\rightarrow$ & $\begin{array}{c}\text { Cracking } \\
\downarrow\end{array}$ & $\begin{array}{c}\text { Avoid breakage } \\
\text { of kernels }\end{array}$ \\
\hline
\end{tabular}

$$
\begin{aligned}
& \begin{array}{ccc}
\text { At } 5-10 \% \\
\text { moisture content }
\end{array} \rightarrow \quad \text { Drying } \quad \begin{array}{c}
\text { Improves shelf } \\
\text { life }
\end{array} \\
& \downarrow
\end{aligned}
$$

Cater to the

\begin{tabular}{|c|c|c|c|}
\hline $\begin{array}{l}\text { On the basis of } \\
\text { colour and size of } \\
\text { kernels }\end{array}$ & $\rightarrow$ & $\begin{array}{l}\text { Colour } \\
\text { sorting }\end{array}$ & $\begin{array}{l}\text { needs of globa } \\
\text { markets and } \\
\text { graded produc } \\
\text { fetches higher } \\
\text { returns }\end{array}$ \\
\hline
\end{tabular}
needs of global

$\begin{array}{cccc}\begin{array}{c}\text { Nitrogen packing } \\ \text { in silver vacuum } \\ \text { packs }\end{array} & \rightarrow & \begin{array}{c}\text { Summer } \\ \text { packing }\end{array} & \begin{array}{c}\text { Avoid spoilage } \\ \text { and fungal } \\ \text { attach }\end{array} \\ \begin{array}{c}1 / 2,2.5 \text { and } 5 \mathrm{~kg} \\ \text { plastic packs }\end{array} & \rightarrow & \begin{array}{c}\text { Packing for } \\ \text { export }\end{array} & \begin{array}{c}\text { Vacuum packing } \\ \text { for improving } \\ \text { its life and easy }\end{array} \\ & & & \text { transit }\end{array}$

Fumigation of containers using $\rightarrow$ Fumigation infectious things from getting access inside the container methyl bromide

$$
\begin{gathered}
\downarrow \\
\text { Export to } \\
\text { UK, USA, } \\
\text { etc. }
\end{gathered}
$$

Directly or through export agents
Fig. 1: Supply chain of walnut

\section{Price spread in export of walnut in modernized channel}

In modernized channel, processor appears as one of the important functionaries between producers and consumers. Processors either purchase kernels directly or purchase nuts and then they convert it to the kernels in systematic manner to confirm global demand of kernels and dispose it to the global markets.

\section{(a) Value addition for export when procured as nut and exported as kernel by processor}

In these channels, processors purchase walnuts as nuts from trader or directly from farmers. Processor pay them as per grades of walnut. For the fixation of price of the produce, processors categorize procured quantity of walnut into three grades (Table 3). Processors invest a huge amount on value of addition of walnut and make it available in export 
market as kernels of different grades. Although processor categorize kernel into 5 grades, however, price spread for grade viz. Light halves, Light broken, and Light amber halves has been averaged and presented in Table 4

Table 3: Description of walnut grading (nuts as well as of kernels)

\section{For nut grading}

\begin{tabular}{ccc}
\hline Grade name & Code & Nut size \\
Apple & 111 & $33-38 \mathrm{~mm}$ \\
Pear & 555 & $30-33 \mathrm{~mm}$ \\
Cherry & 999 & $27-30 \mathrm{~mm}$ \\
\hline
\end{tabular}

For kernel grading

\begin{tabular}{cc}
\hline Grade name & Grade \\
\hline Extra light half & $1^{\text {st }}$ \\
Light halves & Second \\
Light broken & Third \\
Light amber halves & Fourth \\
Light amber broken & Fifth \\
\hline
\end{tabular}

The price spread of walnut under these channels has been depicted in Table 4. It was observed that farmer's net return increased significantly in channel where he is able to sell his produce directly to processor. It was found that all the functionaries that appear before processor also realized better absolute margins than traditional channels. In proportionate terms, the costs as well as returns to processor would be much high, though his margin was maximum in grade I and lower toward grade III. It implies that the return to each rupee invested as value addition including grading (a proxy of quality improvement) was more. Further, the details of various components of cost invested by processor depicted in Table 4 indicated that maximum cost was invested on fixed capital and on export of produce to other countries.

\section{(b) Value addition for export when procured as kernel and exported by processor}

In this case processor purchased better quality kernels either from trader or directly from farmer. The channel perused for export of kernels has been deputed in Table 5. In these channels either trader or farmers spend on conversion of nuts to kernels and bear the cost of refuse in such conversion. Net return to farmer was better in channel where he is able to sell his produce to processor directly even when his costs were more. In similar manner, margins of trader were more when he sold walnuts as kernel than nuts. Although in these channels the proportionate margin of processor was relatively less than earlier (when he purchased nuts and bear cost of conversion into kernels) but his margin were better than any other functionary in absolute terms. To sum up, net return to farmers were maximum in absolute term in modernized channels. Farmer's returns were relatively more when they sell their produce directly to processor. Further it was observed that farmer per rupee invested on value addition added to the dividends of investor.

Marketing efficiency and margins in different channels were estimated while accounting for marketing loss and margins and are presented in Table 6. Farmer's net returns were higher in absolute and proportionate terms when they sell kernels directly to the processor. Accordingly, marketing efficiency was found more in channels II when the processor purchase nuts and same results are found in channel II when processor purchase kernels from the producer. The marketing margins were more when processors acted as the main functionaries in the channel.

\section{Economies of Value Addition}

Net price received by farmer is more when farmer sold kernels through processor in modernized channel rather than other intermediaries (as in traditional channel Table 7). In modernized channel, more marketing cost was incurred by processor which adds value to the produce and reduces the loss in kernels processing. Despite, more marketing cost in modernized channel processor's margins were seemed to be less which in turn is favourable for the producer to sale its produce through modernized channel. Marketing efficiency was also seen more in case of modernized channel, which emphasized upon the need for grading and scientific manipulation of surplus. Through value addition, integration of walnut production with export marketing would help in harnessing the potential of this crop in domestic and global trade. The whole chain from procurement to export of walnut is beset with number of problems which 
Table 4: Price spread in marketing of kernels (procured as nuts) in modernized channels (₹/qtl)

\begin{tabular}{|c|c|c|c|c|c|c|c|c|c|c|c|c|}
\hline \multirow[b]{2}{*}{ Particulars } & \multicolumn{4}{|c|}{ Grade- I } & \multicolumn{4}{|c|}{ Grade- II } & \multicolumn{4}{|c|}{ Grade- III } \\
\hline & $\begin{array}{c}\text { Channel- } \\
\text { I }\end{array}$ & $\begin{array}{l}\% \\
\text { age }\end{array}$ & $\begin{array}{l}\text { Channel- } \\
\text { II }\end{array}$ & $\begin{array}{c}\% \\
\text { age }\end{array}$ & $\begin{array}{c}\text { Channel- } \\
\text { I }\end{array}$ & $\begin{array}{c}\% \\
\text { age }\end{array}$ & $\begin{array}{l}\text { Channel- } \\
\text { II }\end{array}$ & $\begin{array}{l}\% \\
\text { age }\end{array}$ & $\begin{array}{c}\text { Channel- } \\
\text { I }\end{array}$ & $\begin{array}{c}\% \\
\text { age }\end{array}$ & $\begin{array}{l}\text { Channel- } \\
\text { II }\end{array}$ & $\begin{array}{c}\% \\
\text { age }\end{array}$ \\
\hline \multicolumn{13}{|c|}{ Farmer's level } \\
\hline Harvesting charge & 984.00 & 0.58 & 984.00 & 0.58 & 984.00 & 0.60 & 984.00 & 0.60 & 984.00 & 0.65 & 984.00 & 0.65 \\
\hline Assembling charge & 217.00 & 0.13 & 217.00 & 0.13 & 217.00 & 0.13 & 217.00 & 0.13 & 217.00 & 0.14 & 217.00 & 0.14 \\
\hline Dehulling & 124.00 & 0.07 & 124.00 & 0.07 & 124.00 & 0.08 & 124.00 & 0.08 & 124.00 & 0.08 & 124.00 & 0.08 \\
\hline Cost of weight loss & 272.00 & 0.16 & 272.00 & 0.16 & 272.00 & 0.17 & 272.00 & 0.17 & 272.00 & 0.18 & 272.00 & 0.18 \\
\hline Drying charge & 161.20 & 0.09 & 161.20 & 0.09 & 161.20 & 0.10 & 161.20 & 0.10 & 161.20 & 0.11 & 161.20 & 0.11 \\
\hline Packing charge & 102.00 & 0.06 & 102.00 & 0.06 & 102.00 & 0.06 & 102.00 & 0.06 & 102.00 & 0.07 & 102.00 & 0.07 \\
\hline Local charge & 63.00 & 0.04 & 63.00 & 0.04 & 63.00 & 0.04 & 63.00 & 0.04 & 63.00 & 0.04 & 63.00 & 0.04 \\
\hline Transport charge & 0.00 & 0.00 & 187.50 & 0.11 & 0.00 & 0.00 & 187.50 & 0.11 & 0.00 & 0.00 & 187.50 & 0.12 \\
\hline $\begin{array}{l}\text { Miscellaneous } \\
\text { charges }^{*}\end{array}$ & 30.00 & 0.02 & 32.50 & 0.02 & 30.00 & 0.02 & 32.50 & 0.02 & 30.00 & 0.02 & 32.50 & 0.02 \\
\hline Total cost & 1953.20 & 1.15 & 2143.20 & 1.26 & 1953.20 & 1.19 & 2143.20 & 1.30 & 1953.20 & 1.29 & 2143.20 & 1.42 \\
\hline Loss & 217.15 & 0.13 & 371.00 & 0.22 & 217.15 & 0.13 & 371.00 & 0.23 & 217.15 & 0.14 & 371.00 & 0.25 \\
\hline Sale price & 19250.00 & 11.29 & 37100.00 & 21.76 & 19250.00 & 11.69 & 37100.00 & 22.53 & 19250.00 & 12.76 & 37100.00 & 24.59 \\
\hline Net price received & 17079.65 & 10.02 & 34585.80 & 20.28 & 17079.65 & 10.37 & 34585.80 & 21.00 & 17079.65 & 11.32 & 34585.80 & 22.92 \\
\hline \multicolumn{13}{|c|}{ Trader's level } \\
\hline Purchasing price & 19250.00 & 11.29 & - & - & 19250.00 & 11.69 & - & - & 19250.00 & 12.76 & - & - \\
\hline $\begin{array}{l}\text { Collection from } \\
\text { various places }\end{array}$ & 53.00 & 0.03 & - & - & 53.00 & 0.03 & - & - & 53.00 & 0.04 & - & - \\
\hline $\begin{array}{l}\text { Loading and } \\
\text { unloading }\end{array}$ & 10.00 & 0.01 & - & - & 10.00 & 0.01 & - & - & 10.00 & 0.01 & - & - \\
\hline Transport charge & 182.00 & 0.11 & - & - & 182.00 & 0.11 & - & - & 182.00 & 0.12 & - & - \\
\hline Total cost & 245.00 & 0.14 & - & - & 245.00 & 0.15 & - & - & 245.00 & 0.16 & - & - \\
\hline Loss & 264.95 & 0.16 & - & - & 264.95 & 0.16 & - & - & 264.95 & 0.18 & - & - \\
\hline Sale price of nut & 37850.00 & 22.20 & - & - & 37850.00 & 22.98 & - & - & 37850.00 & 25.09 & - & - \\
\hline Margin & 18090.05 & 10.61 & - & - & 18090.05 & 10.98 & - & - & 18090.05 & 11.99 & - & - \\
\hline \multicolumn{13}{|c|}{ Processor's level } \\
\hline Purchase price & 37850.00 & 22.20 & 37100.00 & 21.76 & 37850.00 & 22.98 & 37100.00 & 22.53 & 37850.00 & 25.09 & 37100.00 & 24.59 \\
\hline $\begin{array}{l}\text { Assembling from } \\
\text { growers }\end{array}$ & 106.00 & 0.06 & 106.00 & 0.06 & 106.00 & 0.06 & 106.00 & 0.06 & 106.00 & 0.07 & 106.00 & 0.07 \\
\hline Loading & 20.00 & 0.01 & 20.00 & 0.01 & 20.00 & 0.01 & 20.00 & 0.01 & 20.00 & 0.01 & 20.00 & 0.01 \\
\hline Unloading & 20.00 & 0.01 & 20.00 & 0.01 & 20.00 & 0.01 & 20.00 & 0.01 & 20.00 & 0.01 & 20.00 & 0.01 \\
\hline Quality check & 20.00 & 0.01 & 20.00 & 0.01 & 20.00 & 0.01 & 20.00 & 0.01 & 20.00 & 0.01 & 20.00 & 0.01 \\
\hline Walnut grading & 27.50 & 0.02 & 27.50 & 0.02 & 27.50 & 0.02 & 27.50 & 0.02 & 27.50 & 0.02 & 27.50 & 0.02 \\
\hline Soaking & 27.00 & 0.02 & 27.00 & 0.02 & 27.00 & 0.02 & 27.00 & 0.02 & 27.00 & 0.02 & 27.00 & 0.02 \\
\hline Cracking & 120.00 & 0.07 & 120.00 & 0.07 & 120.00 & 0.07 & 120.00 & 0.07 & 120.00 & 0.08 & 120.00 & 0.08 \\
\hline Cost of conversion & 510.75 & 0.30 & 510.75 & 0.30 & 510.75 & 0.31 & 510.75 & 0.31 & 510.75 & 0.34 & 510.75 & 0.34 \\
\hline Drying of kernel & 12.80 & 0.01 & 12.80 & 0.01 & 12.80 & 0.01 & 12.80 & 0.01 & 12.80 & 0.01 & 12.80 & 0.01 \\
\hline $\begin{array}{l}\text { Mechanical } \\
\text { grading of kernel }\end{array}$ & 21.23 & 0.01 & 21.23 & 0.01 & 21.23 & 0.01 & 21.23 & 0.01 & 21.23 & 0.01 & 21.23 & 0.01 \\
\hline Colour sorting & 360.00 & 0.21 & 360.00 & 0.21 & 360.00 & 0.22 & 360.00 & 0.22 & 360.00 & 0.24 & 360.00 & 0.24 \\
\hline Packing & 494.00 & 0.29 & 494.00 & 0.29 & 494.00 & 0.30 & 494.00 & 0.30 & 494.00 & 0.33 & 494.00 & 0.33 \\
\hline Carton & 305.00 & 0.18 & 305.00 & 0.18 & 305.00 & 0.19 & 305.00 & 0.19 & 305.00 & 0.20 & 305.00 & 0.20 \\
\hline Aluminium foil & 209.00 & 0.12 & 209.00 & 0.12 & 209.00 & 0.13 & 209.00 & 0.13 & 209.00 & 0.14 & 209.00 & 0.14 \\
\hline Tape/patri & 96.00 & 0.06 & 96.00 & 0.06 & 96.00 & 0.06 & 96.00 & 0.06 & 96.00 & 0.06 & 96.00 & 0.06 \\
\hline
\end{tabular}


Fumigation of container

Freight upto Mumbai

Freight upto major importing countries

Handling charges of export agent

Miscellaneous charges*

Cost of fixed capital

Total cost Loss

Export price Margin

Export price

$\begin{array}{rrrrrrrrrrrr}12.00 & 0.01 & 12.00 & 0.01 & 12.00 & 0.01 & 12.00 & 0.01 & 12.00 & 0.01 & 12.00 & 0.01 \\ 572.00 & 0.34 & 572.00 & 0.34 & 572.00 & 0.35 & 572.00 & 0.35 & 572.00 & 0.38 & 572.00 & 0.38\end{array}$

$\begin{array}{llllllllllll}1173.00 & 0.69 & 1173.00 & 0.69 & 1173.00 & 0.71 & 1173.00 & 0.71 & 1173.00 & 0.78 & 1173.00 & 0.78\end{array}$

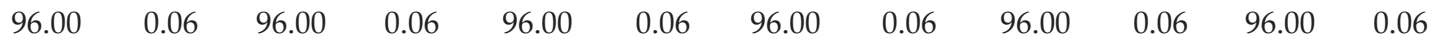

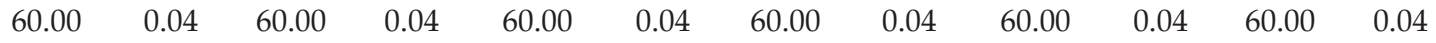
$\begin{array}{llllllllllll}17100.00 & 10.03 & 17100.00 & 10.03 & 17100.00 & 10.38 & 17100.00 & 10.38 & 17100.00 & 11.33 & 17100.00 & 11.33\end{array}$ $\begin{array}{llllllllllll}21362.28 & 12.53 & 21362.28 & 12.53 & 21362.28 & 12.97 & 21362.28 & 12.97 & 21362.28 & 14.16 & 21362.28 & 14.16\end{array}$ $\begin{array}{llllllllllll}3324.75 & 1.95 & 3324.75 & 1.95 & 2964.42 & 1.80 & 2964.42 & 1.80 & 2746.02 & 1.82 & 2746.02 & 1.82\end{array}$

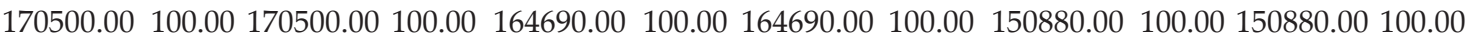

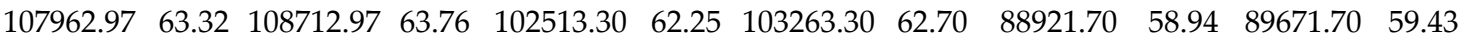
$170500.00100 .00170500 .00100 .00164690 .00 \quad 100.00164690 .00100 .00150880 .00100 .00150880 .00100 .00$

Table 5: Price spread in marketing of kernels (procured as kernels) in modernized channels (₹/qtl)

\begin{tabular}{|c|c|c|c|c|c|c|c|c|c|c|c|c|}
\hline \multirow[b]{2}{*}{ Particulars } & \multirow[b]{2}{*}{$\begin{array}{l}\text { Channel- } \\
\text { III }\end{array}$} & \multicolumn{3}{|c|}{ Grade- I } & \multicolumn{4}{|c|}{ Grade- II } & \multicolumn{4}{|c|}{ Grade- III } \\
\hline & & $\begin{array}{c}\% \\
\text { age }\end{array}$ & $\begin{array}{l}\text { Channel- } \\
\text { IV }\end{array}$ & $\begin{array}{c}\% \\
\text { age }\end{array}$ & $\begin{array}{l}\text { Channel- } \\
\text { III }\end{array}$ & $\begin{array}{c}\% \\
\text { age }\end{array}$ & $\begin{array}{l}\text { Channel- } \\
\text { IV }\end{array}$ & $\begin{array}{c}\% \\
\text { age }\end{array}$ & $\begin{array}{l}\text { Channel- } \\
\text { III }\end{array}$ & $\begin{array}{c}\% \\
\text { age }\end{array}$ & $\begin{array}{l}\text { Channel- } \\
\text { IV }\end{array}$ & $\begin{array}{c}\% \\
\text { age }\end{array}$ \\
\hline \multicolumn{13}{|c|}{ Farmer's level } \\
\hline $\begin{array}{l}\text { Harvesting } \\
\text { charge }\end{array}$ & 984.00 & 0.58 & 984.00 & 0.58 & 984.00 & 0.60 & 984.00 & 0.60 & 984.00 & 0.65 & 984.00 & 0.65 \\
\hline $\begin{array}{l}\text { Assembling } \\
\text { charge }\end{array}$ & 217.00 & 0.13 & 217.00 & 0.13 & 217.00 & 0.13 & 217.00 & 0.13 & 217.00 & 0.14 & 217.00 & 0.14 \\
\hline Dehulling & 124.00 & 0.07 & 124.00 & 0.07 & 124.00 & 0.08 & 124.00 & 0.08 & 124.00 & 0.08 & 124.00 & 0.08 \\
\hline $\begin{array}{c}\text { Cost of weight } \\
\text { loss }\end{array}$ & 272.00 & 0.16 & 272.00 & 0.16 & 272.00 & 0.17 & 272.00 & 0.17 & 272.00 & 0.18 & 272.00 & 0.18 \\
\hline Drying charge & 161.20 & 0.09 & 161.20 & 0.09 & 161.20 & 0.10 & 161.20 & 0.10 & 161.20 & 0.11 & 161.20 & 0.11 \\
\hline Local charge & 63.00 & 0.04 & 63.00 & 0.04 & 63.00 & 0.04 & 63.00 & 0.04 & 63.00 & 0.04 & 63.00 & 0.04 \\
\hline $\begin{array}{c}\text { Pre cracking } \\
\text { charge }\end{array}$ & 1821.20 & 1.07 & 1821.20 & 1.07 & 1821.20 & 1.11 & 1821.20 & 1.11 & 1821.20 & 1.21 & 1821.20 & 1.21 \\
\hline Cracking charge & 1400.00 & 0.82 & 1400.00 & 0.82 & 1400.00 & 0.85 & 1400.00 & 0.85 & 1400.00 & 0.93 & 1400.00 & 0.93 \\
\hline $\begin{array}{c}\text { Cost of } \\
\text { conversion }\end{array}$ & 4383.30 & 2.57 & 4383.30 & 2.57 & 4383.30 & 2.66 & 4383.30 & 2.66 & 4383.30 & 2.91 & 4383.30 & 2.91 \\
\hline Grading charge & 700.00 & 0.41 & 700.00 & 0.41 & 700.00 & 0.43 & 700.00 & 0.43 & 700.00 & 0.46 & 700.00 & 0.46 \\
\hline Packing charge & 395.00 & 0.23 & 395.00 & 0.23 & 395.00 & 0.24 & 395.00 & 0.24 & 395.00 & 0.26 & 395.00 & 0.26 \\
\hline $\begin{array}{c}\text { Transport } \\
\text { charge }\end{array}$ & 0.00 & 0.00 & 400.00 & 0.23 & 0.00 & 0.00 & 400.00 & 0.24 & 0.00 & 0.00 & 400.00 & 0.27 \\
\hline $\begin{array}{l}\text { Miscellaneous } \\
\text { charges* }\end{array}$ & 30.00 & 0.02 & 33.50 & 0.02 & 30.00 & 0.02 & 33.50 & 0.02 & 30.00 & 0.02 & 33.50 & 0.02 \\
\hline Total cost & 8729.50 & 5.12 & 9133.00 & 5.36 & 8729.50 & 5.30 & 9133.00 & 5.55 & 8729.50 & 5.79 & 9133.00 & 6.05 \\
\hline Loss & 1896.86 & 1.11 & 2676.70 & 1.57 & 1911.79 & 1.16 & 2958.53 & 1.80 & 1713.75 & 1.14 & 2953.44 & 1.96 \\
\hline Sale price & 74387.50 & 43.63 & 102950.00 & 60.38 & 62375.00 & 37.87 & 97700.00 & 59.32 & 57125.00 & 37.86 & 90875.00 & 60.23 \\
\hline $\begin{array}{l}\text { Net price } \\
\text { received }\end{array}$ & 63724.94 & 37.40 & 91104.10 & 53.45 & 51969.71 & 31.41 & 85844.48 & 51.98 & 46917.75 & 31.10 & 77089.38 & 51.09 \\
\hline
\end{tabular}




\section{Traders level}

Purchasing price

Collection from

various places

Loading and

unloading

Transport

charge

Total cost

Loss

Sale price of nut

Margin

\section{$74387.50 \quad 43.63$}

$15.00 \quad 0.01$

$355.00 \quad 0.21$

$423.00 \quad 0.25$

$1035.12 \quad 0.61$

103512.5

27666.88

$-$

$-\quad 62375.00 \quad 37.87$

$\begin{array}{lll}- & 53.00 \quad 0.03\end{array}$

$\begin{array}{lll}-\quad & 15.00 \quad 0.01\end{array}$

$\begin{array}{lll}-\quad 355.00 & 0.22\end{array}$

- $423.00 \quad 0.26$

- $\quad 1069.56 \quad 0.65$

- 98125.0059 .58

- $\quad 34257.4420 .80$

\section{Processor's level}

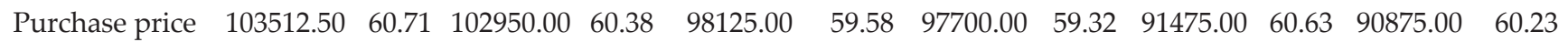
Assembling from growers Loading

Unloading

$106.00 \quad 0.06 \quad 106.00 \quad 0.06$

Quality check

$$
20.00 \quad 0.01
$$

$20.00 \quad 0.01 \quad 20.00$

20.00

0.01

20.00

$0.01 \quad 20.00$

$20.00 \quad 0.01$

20.00

0.01

20.00

Drying of kernel

12.80

0.01

12.80

$0.01 \quad 20.00$

Mechanical

grading of kernel

\section{Colour sorting} Packing

21.23

$$
0.01
$$

0.01

12.80

0.06

0.01

0.01

0.01

0.01

106.00

20.00

20.00

20.00

12.80

0.06

106.00

$\begin{array}{lllll}0.01 & 20.00 & 0.01 & 20.00 & 0.01\end{array}$

$\begin{array}{lllll}0.01 & 20.00 & 0.01 & 20.00 & 0.01\end{array}$

$\begin{array}{lllll}0.01 & 20.00 & 0.01 & 20.00 & 0.01\end{array}$

\section{Carton}

Aluminium foil

Tape/patri

Fumigation of container

Freight upto Mumbai

Freight upto

major importing countries

Handling

charges of

export agent

Miscellaneous charges*

Cost of fixed capital

Total cost

Loss

Export price

360.00

0.21

360.00

0.01

21.23

0.01

21.2

0.01

12.80

$0.01 \quad 12.80 \quad 0.01$

494.00

0.29

494.00

$0.21 \quad 360.00$

0.22

360.00

0.01

21.23

0.01

21.23

0.01

305.00

0.18

305.00

0.29

494.00

0.30

494.00

0.22

360.00

$0.24 \quad 360.00$

0.24

209.00

0.12

209.00

0.18

305.00

0.19

305.00

0.30

494.00

0.33

0.19

305.00

0.20

494.00

0.33

96.00

0.06

96.00

0.06

209.00

0.13

209.00

0.13

209.00

0.14

0.20

12.0

0.01

12.00

0.01

12.00

0.06

96.00

0.06

96.00

0.06

09.00

0.14

$0.01 \quad 12.0$

0.01

$0.35 \quad 572.00$

0.35

572.00

0.38

1173.00

0.69

1173.00

0.69

1173.00

0.71

1173.00

0.71

1173.0

0.7

96.00

0.06

96.00

0.06

96.00

0.06

60.00

$0.04-60.00$

$0.04 \quad 60.00$

0.04

60.0

0.04

60.00

0.04

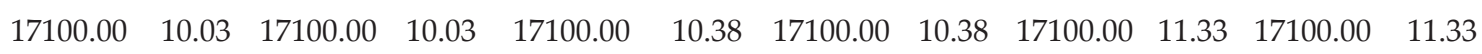

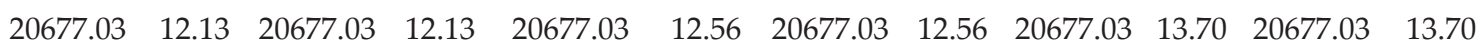

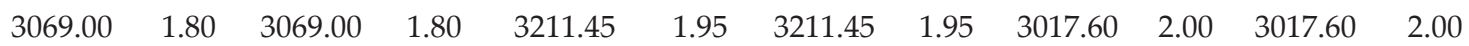

$\begin{array}{llllllllllll}170500.00 & 100.0 & 170500.00 & 100.00 & 164690.00 & 100.00 & 164690.00 & 100.00 & 150880.00 & 100.0 & 150880.00 & 100.00\end{array}$ Margin

$\begin{array}{llllllllllll}43241.47 & 25.36 & 43803.97 & 25.69 & 42676.52 & 25.91 & 43101.52 & 26.17 & 35710.37 & 23.67 & 36310.37 & 24.07\end{array}$

Export price

$\begin{array}{llllll}170500.00 & 100.0 & 170500.00 & 100.00 & 164690.00\end{array}$

*Receipt/phone call charges 
Table 6: Marketing efficiency indicator in modernized channels of walnut

\begin{tabular}{|c|c|c|c|c|c|}
\hline & $\begin{array}{l}\text { Net price receive } \\
\text { by farmer (₹/qtl) }\end{array}$ & $\begin{array}{l}\text { Marketing cost } \\
(₹ / q \text { qtl) }\end{array}$ & $\begin{array}{l}\text { Marketing } \\
\text { loss (₹/qtl) }\end{array}$ & $\begin{array}{l}\text { Marketing margin } \\
\text { (₹/qtl) }\end{array}$ & $\begin{array}{c}\text { Marketing } \\
\text { efficiency }\end{array}$ \\
\hline \multicolumn{6}{|c|}{ (A) When procured by processor as nuts and exported as kernels } \\
\hline \multicolumn{6}{|c|}{ Grade I } \\
\hline Channel I & 17315.65 & 23260.68 & 3193.10 & 109866.77 & 0.13 \\
\hline Channel II & 34818.00 & 23205.68 & 3082.00 & 92526.72 & 0.29 \\
\hline \multicolumn{6}{|l|}{ Grade II } \\
\hline Channel I & 17315.65 & 23260.68 & 3446.52 & 103803.35 & 0.13 \\
\hline Channel II & 34818.00 & 23205.68 & 3335.42 & 86463.30 & 0.31 \\
\hline \multicolumn{6}{|l|}{ Grade III } \\
\hline Channel I & 17315.65 & 23800.40 & 3233.94 & 90206.18 & 0.15 \\
\hline Channel II & 34818.00 & 23205.68 & 3085.40 & 72903.32 & 0.35 \\
\hline \multicolumn{6}{|c|}{ (B) When procured by processor as nuts and exported as kernels } \\
\hline \multicolumn{6}{|c|}{ Grade I } \\
\hline Channel I & 63724.94 & 29565.73 & 6000.98 & 71208.35 & 0.60 \\
\hline Channel II & 91104.10 & 29546.23 & 6745.70 & 44103.97 & 1.15 \\
\hline \multicolumn{6}{|l|}{ Grade II } \\
\hline Channel I & 51969.71 & 29565.73 & 6192.81 & 77233.96 & 0.46 \\
\hline Channel II & 85844.48 & 29546.23 & 6169.99 & 43401.52 & 1.09 \\
\hline \multicolumn{6}{|l|}{ Grade III } \\
\hline Channel I & 46917.75 & 29565.73 & 6377.90 & 68290.82 & 0.45 \\
\hline Channel II & 77089.38 & 29546.23 & 5971.03 & 36610.37 & 1.07 \\
\hline
\end{tabular}

Table 7: Economies of value addition

\begin{tabular}{ccccccc}
\hline & \multicolumn{3}{c}{ Traditional channel of kernels } & \multicolumn{2}{c}{ Modernized channel of kernels } \\
\cline { 2 - 7 } Particulars & Grade I & Grade II & Grade III & Grade I & Grade II & Grade III \\
\hline Net price received by farmer & 63724.94 & 51969.71 & 46917.75 & 91104.1 & 85844.48 & 77089.38 \\
Marketing cost & 9266.5 & 9266.5 & 9266.5 & 29546.23 & 29546.23 & 29546.23 \\
Marketing loss & 9622.74 & 9000.48 & 8962.86 & 6745.7 & 6169.99 & 5971.03 \\
Marking margin & 58599.63 & 59837.72 & 53838.9 & 44103.97 & 43401.52 & 36610.37 \\
Marketing efficiency & 0.82 & 0.66 & 0.65 & 1.13 & 1.09 & 1.07 \\
\hline
\end{tabular}

requires immediate attention by Government. The very important problems reported by the exporters were insufficient availability of raw material for value addition, Despite huge demand of walnut at National and International markets, the production is much less as reflected by processor, which creates supply-demand gaps, poor role of Government agencies and due to this, the respondents have shown serious concerns regarding poor performance of Government in conduct of trainings and human resource development of walnut growers. Majority of the interventions under "technology mission" are not directly related with production-led-walnut system. Although, technology mission has been launched for augmenting the area and productivity of horticultural crops only few interventions are being directed for the development of walnut production in the state, lack of skilled workers like chattered officers, etc., poor export consultancy services, absence of organic certification agencies around production centers, costly institutional credit and delayed payment of subsidies are major problems as perceived by private enterprise. Costly and cumbersome loaning procedure of institutional credit was another problem highlighted by the respondents. Besides, some other problems as cited above were also highlighted by the respondent. 


\section{CONCLUSION AND POLICY IMPLICATION}

An attempt was made in this study to analyze losses and modernized value chain of walnut in J\&K. It was observed that processor invest huge amount in the generation of essential capital at processing establishment. Farmers were found to receive a good absolute amount of their produce from processors compared to other functionaries. Processing of walnut is a capital intensive venture, where in huge value is added to the produce and at the same time good margins accrue to the processor. This sector was reported to have a good potential though it was beset with a number of problems. On the basis of findings, the following policy suggestions can be put forth:

1. Through value addition, integration of walnut of production with export marketing would help in harnessing the potential of this crop in domestic and global trade. Moreover, research in these areas has great pay off by way of quality improvement.

2. The emphasis upon quality improvement would also help to get better prices for walnut produce in the global markets.

3. Small-scale processing units need to be established at the farm and block levels. Moreover, various institutions should be strengthening to provide cheap and easy credit to the farmers and private walnut enterprises.
4. Private enterprises after packing their produce carry them to other states of the country for organic certification and provision of such facilities around production centers would ease their effort in this direction. Further there is a need to give free export consultation to these enterprises.

\section{REFERENCES}

Acharya, S.S. and Agrawal, N.L. 2001. Agricultural Marketing in India. Oxford \& IBH Publishing Company, New Delhi.

Eckert, J.W. 1978. Post-harvest diseases of citrus fruits: out-look on agriculture, 9: 225-232.

Gajanana, T.M. 2002. Marketing practices and post-harvest loss assessment of banana var. Poovan in Tamil Nadu, Agril Econ Res Rev., 15(1): 56-65.

Kishore, K., Basavaraja, D.H. and Lviahajanshetti, S.B. 2006. An economic analysis of post-harvest losses in vegetables in Karnataka, Ind Jour Agril Econ., 61(1): 134-146.

Naqvi, S.A. and Dass, H.C. 1994. Assessment of post-harvest losses in Nagpur mandarin -A pathological perspective. Plant Disease Research, 9(2): 218.

Singh, D. and Jain, R.K. 2004. Post-harvest losses in distant marketing of kinnow. Plant Disease Research, 15(1): 36-39.

Sreenivasa, M.D., Gajanana, T.M., Sudha, M. and Subramanyam, K.V. 2002. Post-harvest loss estimation in mango at different stages of marketing; A methodological perspective, Agril. Econ. Res. Rev., 15(2): 188-200. 